\title{
Sistematični pregled literature s področja ambivalentnega seksizma
}

Mojca Svetek* Ljubljana

Povzetek: Pojavne oblike seksizma so pod stalnim vplivom družbenih sprememb in odnosov med spoloma. V pričujočem članku predstavljam sodobne oblike seksizma, s poudarkom na teoriji ambivalentnega seksizma (Glick in Fiske, 1996), ki obravnava seksizem ne samo na družbeni, ampak tudi na medosebni in osebni ravni. Prispevek nudi obsežen pregled empiričnih ugotovitev s področja dobronamernega in sovražnega seksizma ter njunih učinkov na intimne medosebne odnose, spolno nasilje, lepotne ideale in prakse, samopodobo ter karierne odločitve in aspiracije žensk. Na koncu teorijo ambivalentnega seksizma umestim v širše družbenopsihološke mehanizme in razmišljam o možnostih preseganja seksističnih ideologij in praks.

Ključne besede: ambivalentni seksizem, dobronamerni seksizem, sovražni seksizem, odnosi med spoloma, psihološko opolnomočenje

\section{A systematic literature review on ambivalent sexism}

Mojca Svetek*

Ljubljana, Slovenia

\begin{abstract}
Manifestations of sexism are under the constant influence of social changes and changes in gender relations. This paper presents modern forms of sexism, with an emphasis on the ambivalent sexism theory (Glick and Fiske, 1996). Ambivalent sexism theory addresses sexism not only on societal but also on interpersonal and personal level. In addition, this article provides a comprehensive review of the empirical findings in the field of benevolent and hostile sexism and their effect on close relations, sexual violence, beauty ideals and practices, women's self-esteem, and their career decisions and aspirations. Finally, I place ambivalent sexism theory into the broader societal and psychological context and discuss the possibilities of surmounting current sexist ideologies and practices.
\end{abstract}

Key words: ambivalent sexism, benevolent sexism, hostile sexism, gender relations, psychological empowerment

\footnotetext{
*Naslov/Address: Mojca Svetek, e-mail: mojcasvetek92@gmail.com

Članek je licenciran pod pogoji Creative Commons Attribution 4.0 International licence. (CC-BY licenca). The article is licensed under a Creative Commons Attribution 4.0 International License (CC-BY license).
} 


\section{Od staromodnih do modernih predsodkov - od staromodnega do modernega seksizma}

Seksizem na splošno pomeni diskriminacijo na podlagi spola. Socialnopsihološke raziskave, ki so preučevale seksizem, so do sredine 90. let prejšnjega stoletja skoraj izključno poudarjale predvsem sovražno držo oziroma antipatijo do žensk, praviloma s strani moških. Seksizem kot oblika predsodkov temelji na neupravičenih (praviloma negativnih) stališčih do določenega spola, prepričanjih o lastnostih pripadnikov tega spola ter razlikah s pripadniki drugega spola, ki so nosilci vrednostnih sodb. Predsodki delujejo kot nekakšna mikroideologija, ki podpira mikrostrukturo delitve moči $\mathrm{v}$ vsakdanjem svetu (Ule, 2009), in je, kakor je za ideologijo značilno, mnogokrat izven polja zavedanja. Posledično na eni strani podpira obstoječo strukturo delitve moči (ki v tem primeru izhaja iz ideologije patriarhata), na drugi strani pa se bolj ali manj hitro prilagaja družbenim (strukturnim) spremembam.

Spremembe $\mathrm{v}$ družbenih normah in socialni politiki so močno vplivale na družbeno sprejemljivost nekaterih predsodkov in s tem na način izražanja teh predsodkov (Campbell, Schellenberg in Senn, 1997; Glick in Fiske, 2011; Masser in Abrams, 1999). Raziskovalci na področju rasizma so opazili, da je izražanje rasizma postalo bolj subtilno, averzivno (tj. istočasno zagovarjanje rasne enakosti in doživljanje odpora do določene rasne skupine) in simbolično (tj. na raso posredno vezano prek socialnih in političnih vprašanj) (Crosby, Bromley in Saxe, 1980; Dovidio in Gaertner, 1986; McConahay in Hough, 1976; McConahay, 1986), narava rasizma pa je postala ambivalentna (torej mešanica pozitivnih in negativnih stališč do določene rase) (Katz, 1981; McConahay, 1986). Takšne oblike izražanja rasizma so dobile skupno oznako »moderni rasizem«, medtem ko je termin »staromodni rasizem « označeval nekdaj prevladujočo odprto obliko izražanja diskriminacije.

Dobro desetletje kasneje so tudi raziskovalci na področju seksizma v ZDA (glej: Glick in Fiske, 2011) opazili postopen in konstanten upad povprečnih rezultatov na Lestvici odnosa do žensk (Spence in Helmreich, 1972), in sicer do te mere, da se ta pogosto uporabljena lestvica ni zdela več uporabna za merjenje seksizma. Nekatere postavke (npr. ) Ženske naj bodo bolj osredotočene na to, kako biti dobra žena in mati, kakor na svoje pravice.«; »Ženske naj ne pričakujejo enakih svoboščin kot moški.«; »Družine bi morale sinove bolj spodbujati k šolanju kot hčere.«; »Spodobi se, da ženske nimajo spolnih odnosov pred poroko, četudi so zaročene.«; »Veliko je delovnih mest, kjer bi morali moški imeti pri zaposlovanju prednost pred ženskami.«) te lestvice, ki je bila oblikovana v 70. letih, so se v 90. zdele absurdne in staromodne, zato so raziskovalci (npr. Glick in Fiske, 1996; Swim, Aikin, Hall in Hunter, 1995; Tougas, Brown, Beaton in Joly, 1995) poskušali razviti nove

${ }^{1} \mathrm{~V}$ Sloveniji nimamo prevedenega in standardiziranega nobenega psihološkega pripomočka za merjenje seksizma, kar pomeni, da se lahko prevodi postavk iz tega članka razlikujejo od prevodov v morebitnih bodočih prirejenih različicah omenjenih pripomočkov za slovenski prostor. pripomočke, s katerimi bi lahko izmerili bolj subtilne oblike seksizma, pri čemer so se naslonili na ugotovitve s področja (modernega) rasizma.

Na vzporednice med seksizmom in rasizmom so že v 30 . letih opozarjali aktivistke in aktivisti, v drugi polovici 80 . let pa so na povezavo med seksizmom in rasizmom opozorili tudi nekateri raziskovalci, ki so se ukvarjali s preučevanjem modernega rasizma (pregled v: Swim idr., 1995). J. Swim in sodelavci (1995) so moderni seksizem opredelili kot:

- zanikanje obstoja diskriminacije,

- nasprotovanje zahtevam žensk in

- nasprotovanje posebnim »ugodnostim« za ženske (ukrepom za vzpostavljanje enakosti med spoloma, kot so na primer spolne kvote).

Pri tem so se v celoti vsebinsko oprli na McConahayjev koncept modernega rasizma (McConahay, 1986). Razvili so tudi Lestvico modernega seksizma (Swim idr., 1995), ki vsebuje osem postavk, ki se nanašajo na tri komponente modernega seksizma (npr. »Diskriminacija žensk v ZDA je stvar preteklosti.«) in pet postavk, ki se nanašajo na staromodni seksizem in vključujejo sprejemanje tradicionalnih spolnih vlog, razlikovalen odnos do žensk in moških ter stereotipe o nižji kompetentnosti žensk (npr. »Ženske v povprečju niso tako pametne kot moški.«). Vzporedno so F. Touglas in sodelavci (1995) razvili Lestvico neoseksizma, prav tako opirajoč se na McConahayjevo delo, moderni seksizem (neoseksizem) pa so opredelili kot manifestacijo konflikta med vrednotami enakosti in ostankom negativnih čustev do žensk. Njihovo lestvico sestavlja 11 postavk, od katerih se jih pet nanaša neposredno na področje dela in zaposlitve (npr. »Obstoječi sistem zaposlovanja se mi zdi krivičen do žensk.«), ostale pa predvsem na (ne)upravičene ugodnosti in zahteve (npr. »Ženske zahteve po enakosti med spoloma so preprosto pretirane.«). Čeprav definicija neoseksizma F. Touglas in sodelavcev (1995) v središče postavlja konfliktnost med vrednotami in (negativnim) afektom do žensk, njihova lestvica ne meri konfliktnosti, ampak novejše (subtilnejše) izraze seksizma.

Nasprotno sta Glick in S. T. Fiske (1996, 1997, 2011) dala osrednje mesto pri razvijanju svojega instrumenta prav konfliktni oziroma ambivalentni naravi seksizma. $\mathrm{Na}$ ambivalentno naravo rasizma je med prvimi opozoril Katz (1981) in nekaj let zatem sta A. Eagly in Mladinic (1989) v svoji raziskavi na ameriških študentih obeh spolov empirično pokazala, da študenti ženskam pripisujejo celo bolj pozitivne stereotipe kot moškim (ta ugotovitev je danes znana kot učinek »ženske so čudovite«), čeprav sta njihova družbena moč in status manjša. Povedano drugače, afektivna zaznava lastnosti ni enoznačno povezana $z$ družbenim statusom, ki izhaja iz te dotične lastnosti. Prepričanje, da so ženske čudovite, izvira iz stereotipnega pojmovanja žensk kot komunih in skrbnih bitjih, in se sklada s tradicionalno vlogo žensk, ki ženske potiska izven polja družbenega odločanja in upravljanja ter tako deluje kot pomemben dejavnik diskriminacije žensk.

Odnosi med spoloma pa niso samo družbeno hierarhični, obenem so tudi družinski in romantični, kar predstavlja drugi paradoks, na katerega sta se oprla Glick in S. T. Fiske (1996, 1997, 2011). Tesna intimna povezanost med spoloma spodbuja 
težnjo po vsaj minimalni meri naklonjenosti nasprotnemu spolu, kar pomeni, da na spol vezani predsodki ne morejo biti zgolj odraz antipatije. Prepoznavanje slednjega dejavnika je botrovalo nastanku teorije ambivalentnega seksizma in konceptu dobronamernega seksizma (Glick in Fiske, 1996).

\section{Teorija ambivalentnega seksizma}

Teorija ambivalentnega seksizma (Glick in Fiske, 1996) poskuša pojasniti, kako sta hierarhija med spoloma in hkratna intimna medsebojna odvisnost med spoloma oblikovali vsebino tradicionalnih spolnih ideologij in njihov emocionalni ton. Osredotoča se na a) vsebino ideologij, ki legitimizirajo tradicionalne spolne odnose, b) predpostavlja relativno kulturno univerzalnost, c) preučuje mešana čustva, ki jih zbujajo te ideologije, d) vpliv teh ideologij na odnose med ženskami in moškimi, in e) ponuja pripomočke za njihovo merjenje.

Glick in S. T. Fiske nikakor ne zanikata povezave med neravnovesjem moči med spoloma in sovražnostjo do žensk in priznavata vlogo negativnih (sovražnih) stereotipov pri upravičevanju izkoriščanja žensk, vendar upoštevajoč analizo M. R. Jackman (1994) predpostavljata, da zaradi pogostih in neizogibnih stikov (odnosi med spoloma so zaznamovani $\mathrm{z}$ medsebojno odvisnostjo v spolni in družbeni reprodukciji), razmerja med spoloma najverjetneje niso v celoti sovražna, ampak $\mathrm{v}$ veliki meri temeljijo na t. i. dobronamernih ideologijah, ki služijo pomirjanju napetosti, ki se zaradi neravnovesja moči pojavlja na obeh straneh.

Hkratno neravnovesje $\mathrm{v}$ družbeni moči in (intimna) soodvisnost porajata ambivalentne seksistične ideologije, sestavljene iz sovražnega in dobronamernega seksizma (Glick in Fiske, 1996, 2001). Glick in S. Fiske (2001) sovražni seksizem opredeljujeta kot stališče, da ženske želijo nadzorovati oziroma prevzeti moč nad moškimi bodisi skozi seksualnost bodisi skozi feministično ideologijo, dobronamerni seksizem pa kot navidezno neškodljiva ali celo dopadljiva stališča o ženskah kot o čudovitih bitjih, ki s svojo ljubeznijo dopolnjujejo moške in si zaslužijo občudovanje in zaščito. Medtem ko sovražni seksizem poskuša ohraniti neravnovesja družbene moči in statusa $\mathrm{v}$ prid moškim na manj takten način (prek poskusov kaznovanja odklonov od tradicionalnih spolnih vlog in upravičevanja spolnega objektiviziranja žensk), dobronamerni seksizem ta ista neravnovesja zagovarja na bolj pretanjen in subjektivno pozitiven način, tako da priznava žensko diadično moč (odvisnost moških od žensk) in romantizira odnose med spoloma.

Tako sovražni kakor tudi dobronamerni seksizem opredeljujejo paternalizem, spolna diferenciacija in heteroseksualna komponenta, ki nastopajo bodisi $\mathrm{v}$ bolj dobronamerni bodisi v bolj sovražni pojavni obliki (Glick in Fiske, 1996, 1997). Gospodovalen paternalizem je prepričanje, da morajo moški nadzorovati ženske in vsebuje sovražnost, medtem ko je zaščitniški paternalizem prepričanje, da morajo moški zaščititi in skrbeti za ženske, še posebej tiste, s katerimi so $\mathrm{v}$ bližnjih odnosih, in ima dobronamerno konotacijo. Obema je skupno, da na ženske gledata kot nekompetentne in nesamozadostne, zato pa potrebne nadzora, usmerjanja, zaščite ali skrbi s strani moških oziroma določenega moškega.
Tekmovalna spolna diferenciacija temelji na negativnih stereotipih o ženskah kot manj primernih za določene (predvsem na družbeno moč vezane) vloge, komplimentarna spolna diferenciacija pa črpa iz pozitivnih lastnosti, ki jih ljudje pripisujejo določenemu spolu, in naj bi dopolnjevale drugi spol. Za obe obliki diferenciacije je značilno poudarjanje razlik med spoloma, pri čemer prva oblika predstavlja sovražno naravnanost in odraža občutek ogroženosti s strani žensk, ki se poskušajo uveljaviti v tradicionalno moških vlogah ali se povzpeti po družbeni lestvici, za drugo pa je značilno poudarjanje brezhibnega dopolnjevanja obeh spolov, ki naj bi sicer posedovala različne ali različno močno izražene osebnostne lastnosti. Heteroseksualna sovražnost odraža dojemanje žensk kot spolnih objektov, hkrati pa strah, da bi ženske izkoristile svojo seksualnost proti moškim, intimna heteroseksualnost pa je na drugi strani nasičena $\mathrm{z}$ romantičnim objektificiranjem žensk. Ta komponenta je po mnenju Glicka in S. T. Fiske (1997) najpomembnejši vzrok ambivalentnih odnosov med spoloma, saj težnja moških po intimni bližini z ženskami (ne glede na raven sovražnosti do žensk, večina moških ne želi povsem izključiti žensk iz svojega življenja) pomeni določeno mero ranljivosti. Sovražni seksisti to ranljivost dojemajo kot grožnjo s strani žensk, kar dodatno spodbudi njihovo željo po dominaciji žensk, medtem ko dobronamerni seksisti poskušajo intimne odnose z ženskami približati romantičnim idealom in jih vidijo kot glavni vir sreče in izpolnjenosti v življenju. Ne glede na sovražni ali dobronamerni vidik posamezne komponente je vsem pojavnim različicam ambivalentnega seksizma skupno, da predpostavljajo tradicionalne spolne vloge in služijo ohranjanju patriarhalnih družbenih struktur.

\section{Merjenje ambivalentnega seksizma}

Glick in Fiske sta razvila dva pripomočka za merjenje ambivalentne vsebine spolnih ideologij. Najprej sta razvila Vprašalnik ambivalentnega seksizma (ASI; Glick in Fiske, 1996), ki meri sovražni in dobronamerni seksizem, usmerjen proti ženskam, kasneje pa še Vprašalnik ambivalentnosti do moških (AMI; Glick in Fiske, 1999), ki meri sovražni in dobronamerni seksizem, usmerjen proti moškim. Ker teorija ambivalentnega seksizma izhaja iz interakcije med spolno hierarhijo in tesno medosebno povezanostjo, se trditve $\mathrm{v}$ njunih vprašalnikih $\mathrm{v}$ osnovi nanašajo na odnose med spoloma, medtem ko se Lestvica neoseksizma in Lestvica modernega seksizma bolj osredotočata na večjo oziroma manjšo diskretnost v izražanju spolnih predsodkov in s tem pretežno merita seksizem, kot se odraža $v$ javni sferi. Nobena od omenjenih mer modernega seksizma ne zajema eksplicitno dobronamernega seksizma, saj omenjeni koncept predpostavlja (intimno) soodvisnost, na katero se F. Touglas s sodelavci (1995) ter J. Swim s sodelavci (1995) niso osredotočili pri oblikovanju vsebine pripomočkov, saj so jih osnovali neposredno na podlagi teorij in pripomočkov za merjenje (modernega) rasizma. Stiki med rasami so precej bolj izogibljivi in $\mathrm{v}$ precej manjšem deležu vključujejo razmeroma stalne in intimne odnose, zato ta vidik ni vključen v pripomočke in teorije na področju rasizma, vsaj ne kot osrednji element. Čeprav ambivalentnost opredeljuje 
tudi moderni rasizem, je njen izvor drugačen, (npr. v občutku krivde [belcev], npr. Glick in Fiske, 2011) kot je izvor ambivalentnosti pri seksizmu.

Vprašalnik ambivalentnega seksizma (ASI) vključuje 22 postavk, od katerih se jih 11 nanaša na sovražni seksizem (npr. »Ko ženske zvabijo moške v svoje vajeti, jih navadno poskušajo imeti na kratki vrvici.«) in 11 na dobronamerni seksizem, pri čemer se štiri nanašajo na heteroseksualno intimnost (npr. »Ne glede na svoje dosežke moški ni nikoli izpopolnjen brez ženske ljubezni.«), štiri na zaščitniški paternalizem (npr. »Moški bi morali varovati in skrbeti za ženske.«) ter tri na komplementarno spolno diferenciacijo (npr. »V primerjavi z moškimi imajo ženske boljši občutek za moralnost.«). Vprašalnik ambivalentnosti do moških (AMI) vsebuje 20 postavk, od katerih se jih deset nanaša na sovražni seksizem (zamero moške dominacije in zlorabe moči nad ženskami) in so za razliko od ASI razdeljene še glede na tri komponente, in sicer na paternalistično zamero (npr. »Moški se bodo vedno borili, da bi imeli večji družbeni nadzor kot ženske.«), kompenzatorno spolno diferenciacijo (npr. »Moški bi bili izgubljeni na tem svetu brez žensk.«) in heteroseksualno sovražnost (npr. »Moški navadno želijo pod pretvezo nudenja pomoči ženskam zgolj pokazati, da so boljši od njih.«), deset pa se jih nanaša na dobronamerni seksizem (občudovanje moškega heroizma, prepričanja, da so ženske nepopolne brez moških in da morajo za moške skrbeti) in so, enako kot ASI, razdeljene na tri komponente, in sicer na maternalizem (npr. »Čeprav sta oba partnerja zaposlena, je vloga ženske, da doma poskrbi za svojega moškega.«), komplementarno spolno diferenciacijo (npr. »Moški so se v večji meri pripravljeni izpostaviti nevarnosti, da bi zaščitili druge.«) in heteroseksualno intimnost (npr. »Ženska ne more doseči izpolnjenosti v življenju, brez da bila zavezana dolgotrajnemu odnosu z moškim.«). V osnovi je bil ASI razvit za raziskovanje stališč moških in AMI za raziskovanje stališč žensk, a se je izkazalo, da oba inštrumenta dobro merita stališča obeh spolov (Rudman in Glick, 2010). Prav tako se je, kljub multidimenzionalni naravi obeh vprašalnikov, večina raziskovalcev osredotočila le na skupni rezultat posameznikov na lestvicah dobronamernega in sovražnega seksizma.

\section{Ambivalentni seksizem kot preplet dobronamernega in sovražnega seksizma}

Narava seksizma je ambivalentna prav zaradi komplementarnosti sovražnega in dobronamernega seksizma. Njune komponente imajo namreč nasprotujoče vrednostne implikacije in čustveni ton, a nastopajo skupaj (Glick in Fiske, 1996). Raziskave (npr. Glick idr., 2000; 2004) konsistentno kažejo na (zmerno) pozitivno povezanost dobronamernega in sovražnega seksizma in s tem nakazujejo na morebitno dopolnjujočo naravo teh dveh navidezno nasprotujočih si konstruktov. Upoštevajoč veliko število raziskav, ki ugotavljajo, da hkratna nasprotujoča si prepričanja pri posameznikih vzbujajo občutja tesnobe (t. i. kognitivno disonanco), s tem pa težnjo k spreminjanju teh prepričanj $\mathrm{v}$ smeri njihove konsistentnosti (Myers, 2010), se to lahko zdi nenavadno. Glick, Diebold, Bailey-Werner in Zhu (1997) so $\mathrm{v}$ svoji raziskavi poskušali ugotoviti, zakaj ne prihaja do te napetosti pri posameznikih, ki hkrati izražajo visoko raven dobronamernega in sovražnega seksizma. Rezultati njihove raziskave so potrdili hipotezo, da sta dobronamerni in sovražni seksizem usmerjena proti različnim tipom žensk. Sovražni seksizem je bil napovednik negativnih ocen žensk $\mathrm{v}$ netradicionalnih vlogah (npr. poslovnih žensk, feministk ...), dobronamerni seksizem pa napovednik pozitivnih ocen žensk v tradicionalnih vlogah (npr. gospodinj) (Glick idr., 1997; Rudman in Glick, 2010). Obe obliki seksizma torej spodbujata tradicionalne spolne vloge in ohranjanje razlik v moči med spoloma ter delujeta kot dopolnjujoč sistem nagrajevanja in kaznovanja žensk. Dobronamerni seksizem legitimizira neravnovesje moči med spoloma tako, da nudi nagrade ženskam, ki se prilagodijo tradicionalni spolni vlogi, sovražni pa kaznuje ženske, ki teh vlog ne želijo sprejeti in/ali posegajo na »moška področja«. Po besedah M. R. Jackman (1994) seksizem deluje kot »železna roka v žametni rokavici«; v dobronamernem seksizmu se skriva sovražnost, ki pride do izraza v primeru izzivanja moči in družbenega položaja moških. To, ob upoštevanju intimno-odnosne narave ambivalentnega seksizma, pojasni tudi večjo ogroženost žensk za zlorabe in nasilje s strani moških, s katerimi so v romantičnih odnosih, kakor s strani neznancev. Medosebni odnosi namreč seksistom nudijo več informacij o vedenju in lastnostih posameznic.

Dobronamerni seksizem ni oblika naklonjenosti ženskam, ampak je v svojem bistvu antiegalitarno in tradicionalistično prepričanje. Dobronamerni seksizem je oblika predsodka, ki izhaja iz romantične podobe intimne soodvisnosti med spoloma (Glick in Fiske, 2011). Funkcija romantičnih spolnih ideologij je spodbujanje žensk, da opustijo prizadevanja za svojo neodvisnost (uspeh, denar, moč in status) v zameno za zaščito s strani svojega moškega in s tem ohranjanje deprivilegiranega položaja žensk (Rudman in Glick, 2010).

\section{Ambivalentni seksizem kot dejavnik oblikovanja medosebnih odnosov}

Dobronamerni seksizem črpa neposredno iz romantičnih idealov in na medosebne odnose vpliva preko dveh mehanizmov, in sicer iz izbire partnerja in pripisovanja oziroma prevzemanja tradicionalnih spolnih vlog. Moški, ki imajo visoko izražen dobronamerni seksizem, si želijo partneric, ki še niso imele spolnih odnosov (JohannesenSchmidt in Eagly, 2002, citirano v: Lee, Fiske, Glick in Chen, 2010), mlajše in tiste $\mathrm{z}$ dobrimi kuharskimi in gospodinjskimi spretnostmi (Eastwick idr., 2006). Ženske, ki imajo visoko izražen dobronamerni seksizem, pa si želijo partnerjev, ki so starejši in premožnejši ali pa imajo dober potencial postati premožni (Eastwick idr., 2006; Johannesen-Schmidt in Eagly, 2002, citirano v: Lee idr., 2010; Travaglia, Overall in Sibley, 2009). Čeprav raziskave relativno konsistentno kažejo na razlike med spoloma pri izbiri partnerjev (ženskam je bolj pomemben socialni in finančni status partnerja, moškim pa fizična privlačnost; pregled v Travaglia idr., 2009), so ti vzorci bistveno bolj izraženi pri posameznikih, ki dosegajo visoke rezultate na lestvicah seksizma. Simpson 
in sodelavci (citirano v: Eastwick idr., 2006) menijo, da tradicionalno usmerjeni posamezniki morda bolj poudarjajo relativno objektivne lastnosti in veščine na račun osebnostnih značilnosti in kompatibilnosti.

Dobronamerne ideologije usmerjajo izbor partnerjev tako pri moških kot pri ženskah, medtem ko so sovražne ideologije povezane le z izbirami moških, še posebej tistih, ki prihajajo iz bolj tradicionalnih kultur in kultur $z$ večjim neravnovesjem moči med spoloma (Lee idr., 2010). Sovražne ideologije so namreč privilegij močnejših (torej moških), medtem ko dobronamerne ideologije do neke mere služijo kot nadomestilo šibkejšim za njihovo pokornost in (vsaj delno) odpoved moči. Večja je razlika v moči med spoloma, bolj dopustno je izražati sovražne seksistične ideje in na njihovi podlagi oblikovati zahteve in izbire.

Pri moških so dobronamerne ideologije povezane $\mathrm{z}$ iskanjem tradicionalne (npr. ženske $\mathrm{s}$ tradicionalnimi vrednotami, gospodinje) in tople (prijazne, uvidevne) partnerice (Lee idr., 2010). Dobronamerni seksizem moških se pozitivno povezuje tudi z željo po partnerici s podredljivimi značilnostmi (npr. ustrežljivost in predanost domu) (Chen, Fiske in Lee, 2009). Pri ženskah so dobronamerne ideologije povezane $\mathrm{z}$ iskanjem romantičnega (npr. takšnega partnerja, ki dopolnjuje partnerico), trdnega (npr. samozavestnega partnerja), privlačnega in tradicionalno usmerjenega partnerja (tradicionalnih vrednot in neliberalnih stališč) (Lee idr., 2010) ter dominantnega moškega, ki lahko prevzame vlogo hranilca (Chen idr., 2009). Dobronamerni seksisti imajo odpor do netradicionalnih žensk (nereligioznih, prostaških), dobronamerne seksistke pa do feminilnih (npr. jokavih), odvisnih, nesamozadostnih ter ljubosumnih in vase zagledanih moških (Lee idr., 2010).

$\mathrm{Na}$ drugem polu imamo sovražne ideologije, ki se negativno povezujejo z dimenzijami romantičnosti in bližine in so v zahodnih kulturah negativno povezane $\mathrm{z}$ zahtevami do partnerja. T. Lee in sodelavci (2010) $\mathrm{v}$ tem vidijo pomanjkanje resničnega zanimanja za tesne odnose $\mathrm{z}$ nasprotnim spolom in negativna pričakovanja sovražnih seksistov do nasprotnega spola ter s tem posledično do intimnih medosebnih odnosov samih. Z drugimi besedami, dobronamerne ideologije so povezane $\mathrm{z}$ iskanjem bližine, topline in zaupanja, zlitja in dopolnjevanja med partnerjema ob hkratni jasni opredeljenosti primernih spolnih vlog, medtem ko sovražne ideologije opredeljuje izogibanje bližini (Lee idr., 2010; Travaglia idr., 2009).

Dobronamerni in sovražni seksizem vplivata na oblikovanje odnosov prek selekcije partnerjev, na drugi strani pa $\mathrm{v}$ že vzpostavljenih intimnih medosebnih odnosih pomagata ohranjati moško dominacijo prek predpisovanja primernih spolnih vlog. Moč v medosebnih odnosih pomeni sposobnost vplivanja enega partnerja na drugega, kar se odraža $\mathrm{v}$ pomembnih odločitvah, ki so sprejete $\mathrm{v}$ odnosu oziroma družini (Blood in Wolfe, 1960, citirano v: Chen idr. 2009). Moya, Glick, Expósito, de Lemus, in Hart (2007) v svoji raziskavi ugotavljajo, da je dobronamerni seksizem učinkovit način vplivanja na odločitve žensk, tudi če same ne dosegajo visokih rezultatov na lestvici (dobronamernega) seksizma. Moški so vedenje svojih partneric obvladovali najučinkoviteje, ko so svoje mnenje izrazili na dobronameren način, četudi so njihove partnerice na splošno zavračale dobronamerni seksizem.
Z. Chen s sodelavci (2009) ugotavlja pomembno vlogo sovražnega seksizma pri spodbujanju tradicionalnih spolnih vlog v odnosih (zakonu). Ženske in moški, ki so dosegli visoke rezultate na lestvici sovražnega seksizma, so bili bolj pozorni na normativnost spolnih vlog, še posebej ženskih spolnih vlog. Gospodinjsko delo, podpiranje in vzdrževanje avtoritete moškega ter izogibanje povzročanju občutkov sramu pri partnerju predstavljajo ustrezne vloge za ženske v odnosih, kjer je prisoten sovražen seksizem, za moške pa je zlasti pomembno zasledovanje in doseganje ekonomskega uspeha.

\section{Odnos med ambivalentnim seksizmom, lepotnimi ideali in samopodobo žensk}

Raziskovalci (npr. Forbes, Collinsworth, Jobe, Braun in Wise, 2007; Travaglia idr., 2009) razmeroma konsistentno ugotavljajo, da moški, ki imajo visoko izražen sovražni seksizem, več pomena pripisujejo videzu žensk, njihovi lepoti in vitkosti. Sibley, Wilson in Duckitt (2007) menijo, da sovražno seksistični moški na ženske gledajo kot na trofeje, ki služijo potrditvi njihovega statusa in moči v družbi oziroma določenih socialnih skupinah.

Forbes in sodelavci (2007) so povezavo med pomembnostjo lepotnih idealov in seksizmom našli tudi pri posameznikih, ki so dosegali visoke rezultate na lestvici dobronamernega seksizma, čeprav so bile te nižje kakor pri posameznikih, ki so izstopali na lestvici sovražnega seksizma. Pozitivne povezave med dobronamernim seksizmom in pomenom, ki ga posamezniki pripisujejo lepotnim idealom, so se pokazale pri obeh spolih, a so bile na vzorcu moških višje.

Franzoi (2001) je v svoji študiji predpostavil, da so ženske, ki sprejemajo dobronamerne ideologije, bolj pozorne na svoj videz, da bi vzbudile zanimanje in občudovanje moških, ki bi jim lahko ponudili varnost in prevzeli vlogo hranitelja. Raziskovalci (npr. Forbes, Doroszewicz, Card in Adams-Curtis, 2004; Forbes, Jung in Haas, 2010; Franzoi, 2001) ugotavljajo, da ženske, ki sprejemajo dobronamerne ideologije, dejansko v večji meri posegajo po kozmetičnih sredstvih, a le v primeru, ko pričakujejo stik z moškimi, ki bi lahko potencialno postali njihovi partnerji. Uporaba kozmetičnih sredstev za izboljšanje videza je povezana $s$ pričakovanjem pozitivnih socialnih nagrad, zato je značilna za ženske, ki sprejemajo dobronamerni seksizem, ne pa tudi za tiste, ki sprejemajo sovražni seksizem, kljub temu, da je za obe skupini žensk značilno sprejemanje tradicionalnih spolnih vlog (Franzoi, 2001).

Drugi raziskovalci (npr. Calogero in Jost, 2011; Shepherd idr., 2011) so se osredotočili na učinke, ki jih ima dobronamerni seksizem na samopodobo. Opazovanje dobronamernega seksističnega dogodka pri očividkah poveča samoobjektivizacijo, skrb glede videza in nezadovoljstvo z lastnim telesom (Shepherd idr., 2011). Aktivacija dobronamernih reprezentacij ali kombinacije dobronamernih in sovražnih (ambivalentnih) reprezentacij vpliva na samoobjektivizacijo, povečanje samonadzora in sramu, povezanega s telesom, tudi če izjave, ki so jih udeleženci prebrali, niso bile povezane s telesom ali videzom (Calogero in Jost, 2011). Aktivacija sovražnih reprezentacij ni imela vpliva na samoobjektivizacijo in povezane komponente. 
Pri ženskah, ki so bile izpostavljene dobronamernemu seksizmu ali kombinaciji dobronamernega in sovražnega seksizma, se je povečala tudi namera upravljanja videza v (bližnji) prihodnosti, pri čemer sta kot mediatorski spremenljivki nastopali povečan samonadzor in sram, vezan na telo. Ambivalentni seksizem, še posebej pa dobronamerni seksizem, je torej močno, a subtilno orodje za spodbujanje samoobjektivizacije žensk, spolno normativnega vedenja ter vzdrževanje spolnih norm. Zgolj opomin na dobronamerne in ambivalentne ideologije je očitno dovolj, da izzove skrb in upravljanje videza pri ženskah, zato lahko predpostavljamo, da so učinki na dejanske žrtve dobronamernega seksizma še toliko večji. Pretirana skrb glede videza in ukvarjanje $z$ videzom zahteva psihološke, fizične in finančne vire, kar pomeni manj virov za področja, ki omogočajo uspeh na akademskem, profesionalnem in širšem družbenem področju (Calogero in Jost, 2011).

\section{Vloga ambivalentnega seksizma pri presojanju o spolnem nasilju}

Zaščitništvo dobronamernega seksizma je rezervirano le za tisti tip ženske, ki ustreza tradicionalnim idealom. Raziskovalci (npr. Abrams, Masser in Bohner, 2003; Duran, Moya, Megias in Viki, 2010; Russell in Trigg, 2004; Viki in Abrams, 2002; Viki, Abrams in Masser, 2004) konsistentno ugotavljajo, da so posamezniki, ki dosegajo visoke rezultate na lestvici dobronamernega seksizma, bolj nagnjeni $\mathrm{k}$ pripisovanju krivde žrtvam spolne zlorabe v primerih, ko je storilec znanec žrtve ( ̌̌e posebej, če je žrtvin partner ali zakonec). Pripisovanje krivde žrtvi spolne zlorabe je odvisno tudi od zaznanega kršenja spolnih norm s strani žrtve (npr. potencialne nezvestobe; Viki in Abrams, 2002). To kaže na nagnjenje dobronamernih seksistov $\mathrm{h}$ kategoriziranju žensk in žrtev v kategorijo »dobrih« ali »slabih« žensk, večjemu obsojanju žensk zaradi nenormativnega vedenja in celo upravičevanju zlorabe kot (ustrezne ali pričakovane) posledice vedenja žrtve, ki ga razumejo kot neustreznega.

Tudi dobronamerni seksizem storilca spolne zlorabe igra ključno vlogo pri pripisovanju krivde žrtvi (Duran idr., 2010); če je na primer povzročitelj predstavljen kot dobronamerno seksistični partner žrtve, posamezniki, ki imajo visoko izražen dobronamerni seksizem, krivdo $\mathrm{v}$ večji meri pripisujejo žrtvi. To je še posebej kritično, če upoštevamo prepletenost dobronamernega in sovražnega seksizma $\mathrm{v}$ intimnih medosebnih odnosih. Sovražni seksizem je namreč povezan s tendenco k zagrešitvi spolne zlorabe, še posebej v primerih, ko povzročitelj presodi, da je uporaba nasilja upravičena (Viki idr., 2003). Enako velja tudi za družinsko nasilje (Sakalh, 2001). Upoštevajoč komplementarno naravo in hkratno pojavljanje dobronamernega in sovražnega seksizma pri posameznikih, to nakazuje na ogroženost žensk, ki so vpete v seksistične odnose, pa tudi obsežno nevarnost neustreznega presojanja krivde, tako s strani zunanjih opazovalcev kot tudi storilca samega. Viki s sodelavci (2004) ugotavljajo, da dobronamerni seksizem vpliva na predlagano dolžino kazni za storilca kaznivega dejanja v primeru, ko se storilec in žrtev poznata. B. Russel in K. Trigg (2004) v svoji raziskavi ugotavljata, da kljub v splošnem nižji tolerantnosti žensk do spolnega nasilja $\mathrm{v}$ primerjavi z moškimi, ambivalentni seksizem predstavlja pomembnejši napovednik tolerantnosti kot spol.

Zaznan dobronamerni seksizem storilca ne vpliva zgolj na sodbe zunanjih opazovalcev, temveč tudi na odzive (potencialnih) žrtev. V primeru, ko je bil zlorabljajoč partner prikazan kot dobronamerni seksist, so žrtve uporabile manj aktivnih strategij reagiranja kot $\mathrm{v}$ primeru, ko je bil storilec prikazan kot sovražen ali pa namiga o tem niso prejele. Prav tako so bile strategije reagiranja manj aktivne v primeru, če so žrtve interpretirale agresivno vedenje s strani dobronamernega seksista kot odraz zanimanja in spolne privlačnosti, ki jo storilec čuti do njih (Duran, Moya in Megías, 2014). Težko je trditi, ali do tega pride, ker si žrtve pripišejo krivdo, da so izvale spolno agresivno vedenje storilca, ali žrtve moškim pripisujejo nezmožnost nadzorovanja spolnih impulzov, ali gre za kombinacijo obeh dejavnikov. V vsakem primeru je jasno, da dobronamerni seksizem storilca ne pomeni zgolj nevarnosti prenašanja krivde (in kazni) iz storilca na žrtev, ampak je tudi rizični dejavnik vztrajanja žrtve v zlorabljajočem odnosu.

\section{Ambivalentni seksizem kot mehanizem oblikovanja kariernih možnosti žensk}

Novejše raziskave na temo ambivalentega seksizma so se $\mathrm{v}$ večji meri osredotočile na kognitivne posledice izpostavljenosti seksizmu. Rezultati teh raziskav (npr. Dardenne, Dumont in Bollier, 2007; Dumont, Sarlet in Dardenne, 2010) kažejo, da dobronamerni seksizem vpliva na dosežke žensk na kognitivnih nalogah prek vsiljenih misli o lastni nekompetentnosti. Izpostavljenost dobronamernemu seksizmu namreč olajša dostop do avtobiografskih spominov o nekompetentnosti (Barreto, Ellemers, Piebinga in Moya, 2010). Izpostavljanje stereotipno pozitivnih značilnosti žensk (kar je značilno za dobronamerni seksizem) torej implicitno sporoča žensko nekompetentnost in tako vpliva na dosežke žensk. V nasprotju z dobronamernim seksizmom sovražni seksizem ne sproža misli o nekompetentnosti in nima vpliva na dosežke žrtev. Sovražni seksizem sproža misli, povezane s seksizmom, kar je pokazatelj, da ga žrtve prepoznajo kot seksizem, s tem pa kot neupravičenega in diskriminatornega. $\mathrm{V}$ nasprotju s sovražnim seksizmom ima dobronamerni seksizem bistveno večji potencial ponotranjenja, saj ga žrtve ne prepoznajo kot predsodek, temveč kot do neke mere verodostojno mnenje o ženskah, kar vpliva na oblikovanje njihovega vedenja.

Izpostavljenost seksizmu ima vpliv tudi na sodbe zunanjih opazovalcev o lastnostih in spretnostnih tarče seksizma. J. Good in L. Rudman (2010) sta v svoji raziskavi ugotovili, da dobronamerni seksizem izpraševalcev za zaposlitev vpliva na zaznano kompetentnost in primernost kandidatke za zaposlitev. Posamezniki, ki imajo visoko izražen sovražni seksizem, so kandidatko ocenili bolj strogo v primeru, če je bila izpostavljena dobronamernemu seksizmu s strani izpraševalca. Z drugimi besedami, kandidatko so kaznovali zaradi drugega dobronamerno seksističnega moškega (v tem primeru izpraševalca). To kaže na kompleksno interakcijo 
med sovražnim in dobronamernim seksizmom in pomembne negativne posledice za ženske, ki so izpostavljene obema vrstama seksizma na delovnem mestu. Naklonjenost opazovalcev dobronamerno ali sovražno seksističnemu izpraševalcu, je prav tako igrala pomembno vlogo pri ocenah kompetentnosti in zaposljivosti kandidatke (te so bile $\mathrm{v}$ primeru naklonjenosti nižje), pri čemer so bili opazovalci sovražno seksističnim izpraševalcem na splošno manj naklonjeni kot dobronamerno seksističnim. Naklonjenost seksističnemu vodji se lahko torej izrazi v oteženem vstopu žensk tudi v tiste organizacije, ki temeljijo na praviloma manj rigidnem, karizmatičnem vodenju.

V organizacijah, kjer je prisoten dobronamerni seksizem, se ženske poleg ovir pri zaposlovanju soočajo tudi z ovirami, povezanimi $z$ dodelitvijo nalog in posledično napredovanjem. King in sodelavci (2012) ugotavljajo, da dobronamerne ideologije vplivajo na količino zahtevnih nalog, ki je dodeljena ženskam, in posledično tudi na njihove izkušnje in možnosti za dokazovanje in napredovanje. Čeprav zasedajo enako ali podobno delovno mesto, ženske prejmejo manj pomembne naloge kot njihovi moški sodelavci. Avtorji predpostavljajo, da se učinki dobronamernega seksizma $v$ organizacijah pokažejo že prej, in sicer $\mathrm{v}$ procesu zaposlovanja na delovna mesta (kar eksperimentalno potrjujeta J. Good in L. Rudman, 2010). Ženskam so že a priori dodeljena manj zahtevna delovna mesta in delovna mesta, ki ne omogočajo napredovanja. Dobronamerni seksizem torej lahko predstavlja enega od dejavnikov podreprezentiranosti žensk na vodilnih in odločujočih položajih v organizacijah, politiki in družbi.

Izpostavljenost dobronamernim ideologijam lahko vpliva tudi na same aspiracije žensk. Prisotnost dobronamerno seksističnih ideologij $\mathrm{v}$ družinskem okolju napoveduje dobronamerno seksistična prepričanja hčerk, ta pa negativno njihove akademske cilje (Montanes idr., 2012). Barreto in sodelavci (2010) eksperimentalno ugotavljajo, da se izpostavljenost dobronamernemu seksizmu odraža $\mathrm{v}$ samoopisih in sicer, tarče dobronamernega seksizma so $\mathrm{v}$ samoopisih bolj poudarjale značilnosti, vezane na medosebne odnose (komune značilnosti) kot na nalogo vezane značilnosti, kar pa ni bilo značilno za tiste, ki so bile izpostavljene sovražnemu seksizmu ali pa seksizmu niso bile izpostavljene. Do tega učinka je prihajalo še posebej takrat, ko so pričakovale stik s seksistično osebo. Izpostavljenost dobronamernemu seksizmu je prav tako povečala pripravljenost udeleženk eksperimenta, da predajo vodenje moškemu članu skupine, še posebej, če so pričakovale sodelovanje s seksistično osebo.

Poudarjanje stereotipnih kvalitet žensk ne spodbudi zoperstavljanja stereotipom, ampak njihovo ponotranjenje, kar vpliva na sprejemanje odločitev, ki niso v prid delovnemu uspehu žensk (Barreto idr., 2010). Možno je, da žrtve umik iz vodstvene vloge uporabljajo kot obliko samozaščite, čeprav je to malo verjetno glede na to, da raziskave kažejo (npr. Kilianski in Rudman, 1998), da veliko udeležencev dobronamernega seksizma zaradi njegove subtilne izrazne oblike sploh ne prepozna kot oblike seksizma oziroma diskriminacije (ocene dobronamerno seksističnih izjav so podobne ocenam neseksističnih izjav).

Dodatni dejavnik, ki bi lahko imel vpliv na ambicije žensk, je njihovo lastno sprejemanje dobronamernega seksizma. L.
Rudman in J. Heppen (2003) opozarjata, da romantični ideali predpostavljajo odvisnost žensk od moških. Pričakovanje ekonomskih in družbenih nagrad $\mathrm{v}$ primeru prevzemanja tradicionalnih spolnih vlog bi lahko vplivalo na to, da bi ženske, ki sprejemajo romantične in dobronamerne ideologije, iskale svojo izpolnitev direktno skozi odnose z moškimi in ne skozi lastno ekonomsko neodvisnost.

\section{Družbene posledice ambivalentnega seksizma}

Pogost očitek feminizmu je, da ženske želijo enakost spolov in hkrati koristi, ki izhajajo iz tradicionalnih razmerij med spoloma (torej dobronamerni seksizem po Glick in S. T. Fiske). Kilianski in L. A. Rudman (1998) ugotavljata, da ženske najbolj pozitivno ocenjujejo neseksistične moške, a kljub temu so dobronamerno seksističnim moškim na splošno naklonjene. Sovražne seksiste pa ocenjujejo bistveno bolj negativno kot dobronamerne in neseksistične moške.

Dobronamerni seksizem predstavlja resno oviro pri doseganju enakosti med spoloma iz naslednjih razlogov (Rudman in Glick, 2010):

- posamezniki, ki sprejemajo dobronamerni seksizem, zelo verjetno sprejemajo tudi sovražni seksizem,

- družbe, ki sprejemajo dobronamerni seksizem, kažejo večjo sovražnost do žensk, ki se poskušajo uveljaviti v netradicionalnih vlogah,

- družbe, ki sprejemajo dobronamerni seksizem, imajo nižjo raven enakosti med spoloma,

- zaradi subtilnosti in pozitivnega odziva, ki ga pri žrtvah sproža, dobronamerni seksizem pomaga onemogočati odpor žensk proti obstoječim spolnim neenakostim in

- ženske so najbolj naklonjene dobronamernemu seksizmu v tistih družbah, ki so najbolj sovražno seksistične.

V dveh medkulturnih študijah je Glick s sodelavci (2000, 2004) pokazal, da povezave med dobronamernim in sovražnim seksizmom niso značilne le za posameznike, ampak tudi za družbe (narode) same. Če pri posameznikih veljajo zmerne povezave med obema vrstama seksizma, so te povezave na nacionalni ravni izredno visoke (skoraj $r=0,90$ ) ne glede na to, ali gre za vzorce moških ali žensk. Prav tako je sama višina izraženosti seksizma (še posebej sovražnega s strani moških) povezana s stopnjo neenakosti med spoloma v družbi (Glick idr., 2000; Glick in Fiske, 2001). Stopnja neenakosti med spoloma je torej povezana $\mathrm{z}$ dvema med seboj praktično popolnoma povezanima konstruktoma seksizma $\mathrm{z}$ nasprotno afektivno valenco. Tega ne moremo razumeti brez tega, da bi se naslonili na prepričljivo analizo odnosov med raso, družbenim razredom in spolom M. R. Jackman, (1994). V njej avtorica razmišlja, da ima naklonjenost nosilcev moči do podrejenih ključno vlogo pri ohranjanju njihovega podrejenega položaja. Dominantne skupine lažje upravičijo svoj privilegiran položaj preko paternalističnih (dobronamernih) ideologij kakor preko odkritega antagonizma. Dobronamerne ideologije imajo dvojno funkcijo: na eni strani omogočajo podrejenim skupinam, da $\mathrm{v}$ dominantni skupini vidijo dobrotnika, na 
drugi strani pa omogočajo dominantni skupini, da daje vtis koristnosti in dobrote do podrejenih. Sovražni načini (grožnje, kaznovanje in zbujanje strahu) zatiranja šibkejših skupin $\mathrm{v}$ primerjavi $\mathrm{z}$ dobronamernimi pogosteje izzovejo nasprotovanje in upiranje podrejenih skupin. Vzdrževanje dominantnega položaja s pomočjo sovražnih strategij torej zahteva stalni nadzor, kar pomeni, da tovrstne strategije dolgoročno zahtevajo več virov za ohranjanje obstoječega položaja. Povedano drugače, dobronamerne strategije so bolj učinkovite pri ohranjanju statusa quo, saj namesto upiranja spodbujajo občutke hvaležnosti in naklonjenosti ter zvestost skupin z nižjim statusom. Sovražni načini discipliniranja podrejenih so rezervirani za tiste, pri katerih dobronamerne strategije podrejanja ne zadoščajo. Na primeru seksizma bosta v družbah, ki imajo visoko motivacijo za ohranjanje razlik med spoloma, v večji meri prisotni obe obliki seksizma, pri čemer je dobronamerna oblika $\mathrm{v}$ osnovi bolj ekonomična oblika nadzora, sovražna pa je pridružena kot odgovor na (potencialno) grožnjo obstoječemu neravnovesju moči med spoloma.

Dobronamerni seksizem pomaga razorožiti ženske v boju za enakost med spoloma. Ne le, da je pozitivno konotiran, ta pretanjena oblika seksizma obljublja, da bo moška moč uporabljena v korist žensk (Glick in Fiske, 2001). Že sama misel na dobronamerni seksizem v ženskah obudi občutek pravične družbe (Jost in Kay, 2005), kajti žrtvovanje in odrekanje moških za dobrobit in varnost žensk upravičuje njihov višji družbeni status. Jost in Banaji (citirano v: Jost, Banaji in Nosek, 2004), avtorja teorije upravičevanja sistema (Jost in Banaji, 1994), poudarjata, da ljudje nimajo močne potrebe le po ohranjanju pozitivnega odnosa do sebe in skupin, ki jim pripadajo, ampak tudi po ohranjanju pozitivnega odnosa do družbenega in političnega sistema, v katerega so vpeti. Tej potrebi zadostijo $\mathrm{z}$ racionalizacijo statusa quo in internalizacijo neenakosti (preko naklonjenosti skupini/ skupinam, ki ji/-m ne pripadajo, tj. dominantni/-m skupini/ skupinam, in preko znižanega občutka upravičenosti). Zaradi konflikta med motivi za upravičevanje sistema in motivi za ohranjanje pozitivne podobe jaza ter skupine, kateri posameznik pripada, pripadniki podrejenih skupin oblikujejo ambivalentna stališča. Ključno orodje za upravičevanje sistema so spolni stereotipi in ideologije, ki upravičujejo in naturalizirajo neenakost.

Vse komponente seksizma, ki sta jih identificirala Glick in S. T. Fiske (1996, 1997), temeljijo prav na poudarjanju razlik med spoloma, kar je najbolj očitno pri komponenti spolne diferenciacije. Tudi paternalizem in heteroseksualnost črpata iz stereotipov, ki implicirajo nepremostljive razlike med spoloma, in sicer, paternalizem predpostavlja nežnost in nesamozadostnost žensk ter grobost in zaščitništvo moških, heteroseksualnost pa spolno moč žensk in spolno ranljivost moških. Jost in Kay (2005) sta pravzaprav uspešno pokazala, da ima izpostavljenost komunim in agentnim spolnim stereotipom (npr. »Moški so usmerjeni v dosežke« in »Ženske so usmerjene v odnose«) enak učinek kot izpostavljenost trditvam, ki izhajajo iz Lestvice ambivalentnega seksizma (Glick in Fiske, 1996). Do tega učinka najverjetneje prihaja prav zaradi komplementarne narave spolnih stereotipov in zato, ker seksistične ideologije neposredno črpajo prav iz spolnih stereotipov.

Tisti, ki so najbolj socialno in fizično prikrajšani, razvijejo najmočnejšo težnjo po upravičevanju svojega trpljenja (Wicklund in Brehm, 1976, citirano v Jost idr., 2004). Pomanjkanje moči in subtilna narava dobronamernih ideologij pri teh posameznikih povzroča veliko vrzel, ki zahteva obsežno racionalizacijo. To pojasni rezultate medkulturne študije Glicka s sodelavci (2000; 2004), ki kažejo, da povprečne ravni seksističnih prepričanj žensk lahko prepričljivo napovemo z ravnmi seksističnih prepričanj moških, prav tako se ženske v družbah, v katerih je značilna visoka raven sovražnega seksizma (in sovražnega seksizma s strani moških), še posebej močno oklepajo dobronamernih seksističnih ideologij, kar kaže na težnjo po racionalizaciji obstoječega stanja (Jost in Kay, 2005), pa tudi iskanja zaščite s strani moških (Glick in Fiske, 2001; Rudman in Glick, 2010). $\mathrm{V}$ družbah, kjer je za moške značilna nizka raven sovražnega seksizma, je raven zavračanja dobronamernega seksizma s strani žensk najvišja, kar bi lahko bila posledica nižje ravni strahu pred sovražnim seksizmom moških nad ženskami.

Upravičevanje sistema spodbuja občutek povezanosti in smisla ter spodbuja učinkovito prilagoditev in oblikovanje medosebnih odnosov (Liviatan in Jost, 2011). To je, kot nakazano, še posebej pomembno za posameznike, ki izhajajo iz podrejenih skupin. Na primeru seksizma sta Hammond in Sibley (2011) s pomočjo analize poti pokazala, da ima upravičevanje sistema ključno vlogo pri racionalizaciji obstoječega sistema in preko te vpliva na zadovoljstvo $\mathrm{z}$ življenjem žensk. Dobronamerni seksizem je za ženske torej napovednik zadovoljstva $\mathrm{z}$ življenjem prek mehanizmov upravičevanja sistema, pri moških pa predstavlja neposredni napovednik zadovoljstva. Sovražni seksizem se pozitivno povezuje $\mathrm{z}$ zadovoljstvom z življenjem žensk in moških le $\mathrm{v}$ tistih družbah, kjer je neenakost med spoloma največja (Hammond in Sibley, 2011; Napier, Thorisdottir in Jost, 2010). Čeprav je splošna raven enakosti med spoloma pozitivno povezana s psihološkim blagostanjem žensk in moških, pa ima objektivna neenakost negativen vpliv na subjektivno blagostanje le $\mathrm{v}$ primeru, če posamezniki ne prevrednotijo neenakosti kot pravične in zaželene (Napier idr., 2010). Psihološki mehanizem upravičevanja sistema je zagotovo funkcionalen, saj zagotavlja stabilnost družbe in podrejenim skupina lajša življenje $\mathrm{v}$ družbi (Liviatan in Jost, 2011), a to, kakor sem pokazala, še zdaleč ne implicira njegove neškodljivosti.

\section{Izzivi na področju raziskovanja in preseganja ambivalentega seksizma}

Glavnina študij s področja ambivalentnega seksizma se osredotoča na posledice (eksperimenti) oziroma korelate (korelacijske študije) dobronamernega in sovražnega seksizma na področju romantičnih medosebnih odnosov (Chen idr., 2009; Moya idr., 2007), spolnega nasilja (Duran 
idr., 2010; Duran idr., 2014; Viki in Abrams, 2002; Viki idr., 2003; Viki idr., 2004), samopodobe žensk (Calogero in Jost, 2011; Shepherd idr., 2011) in diskriminacije na delovnem mestu (Good in Rudman, 2010; King idr., 2012) in učinkov na kognitivno učinkovitost žrtev seksizma (Barreto idr., 2010; Dardenne idr., 2007; Dumont idr., 2010). Ugotovitve raziskav so razmeroma konsistentne:

- ambivalentni seksizem ovira doseganje spolne enakosti $\mathrm{v}$ družbi in spodbuja sprejemanje in celo ponotranjenje diskriminatornih spolnih praks;

- zaradi svoje subtilnosti in navidezne neškodljivosti je delovanje dobronamernega seksizma še posebej učinkovito;

- prinaša vrsto negativnih posledic na samopodobo, karierne možnosti in dosežke žensk ter presojanje o spolnem nasilju.

Kljub temu ostaja odprto vprašanje, kakšni so učinki ambivalentnega seksizma na psihološko blagostanje in zadovoljstvo $\mathrm{z}$ življenjem tako žrtev kot tudi nosilcev seksističnih stališč. Na eni strani teorija upravičevanja sistema (Jost in Banaji, 1994) predpostavlja, da ideologije, ki zagovarjajo komplementarnost podrejene in nadrejene družbene skupine (torej tudi ambivalentni seksizem), pomagajo racionalizirati (upravičevati) neravnovesje moči v družbi, s tem pa pripomorejo k zadovoljstvu z življenjem ne le storilcev, ampak tudi žrtev (seksizma) (Connely in Heesacker, 2012; Hammond in Sibley, 2011; Napier idr., 2010). Po drugi strani pa raziskave (Muehlenkamp in Saris-Baglama, 2002; Saunders in Kashubeck-West, 2006) pasivno sprejemanje tradicionalnih spolnih vlog in družbenega položaja ter samoobjektiviziranje, ki so značilni za ambivalentni in dobronamerni seksizem, povezujejo z nizkim psihološkim blagostanjem posameznic.

Drugo teoretsko in empirično nerazrešeno vprašanje pa je, ali sta dobronamerni in sovražni seksizem usmerjena na iste ženske ali različne skupine žensk. Nekateri raziskovalci (Glick idr., 1997) namreč menijo, da se pojavna oblika seksizma razlikuje glede na tip tarče seksizma (seksisti sovražni seksizem izražajo $\mathrm{v}$ odnosu do netradicionalnih žensk, dobronamernega pa $\mathrm{v}$ odnosu do tradicionalnih). Drugi menijo (Chisango, Mayekiso in Thomae, 2015), da je pojavna oblika odvisna predvsem od okoliščin (v socialnih situacijah prevladuje sprejemljivejša oblika seksizma, torej dobronamerni seksizem, v zasebnih pa sovražna različica), tretji (Jackman, 1994) pa predpostavljajo poglavitno vlogo vedenja tarče.

Pervazivnost dobronamernega seksizma v razmeroma spolno egalitarnih družbah lahko pripišemo predvsem njegovi subtilnosti in navidezni neškodljivosti oziroma navidezni nezdružljivosti s sovražnimi oblikami seksizma. Povečanje občutljivosti na subtilne oblike seksizma in prepoznavanje njihove škodljivosti je prvi korak za razvijanje odklonilnega odnosa do njih. Eksperimentalne študije, ki so ugotavljale vpliv ozaveščenosti o škodljivosti in pervazivnosti seksizma (Becker in Swim, 2012) ugotavljajo pomembno vlogo prepoznavanja dobronamernega in modernega seksizma kot škodljivega, medtem ko je vpliv dojemanja pervazivnosti manj enoznačen. Prvič, če seksizem prepoznamo zgolj kot pervaziven, a ne tudi škodljiv, to implicira njegovo neproblematičnost, in drugič, informacija o pervazivnosti lahko pomaga norm(aliz)irati neželeno vedenje (glej: Goldstein in Mortensen, 2012).

Avtorji, ki se ukvarjajo s preučevanjem dejavnikov opolnomočenja posameznic in posameznikov iz deprivilegiranih družbenih skupin, menijo, da je sama informiranost nujen, a ne zadosten pogoj za aktivno prizadevanje za odpravljanje nepravičnosti (pregled v Hur, 2006). Ali bodo posamezniki postali aktivni v prizadevanju za izboljšanje položaja deprivilegirane skupine, je odvisno tudi od njihovih vrednot oziroma presoje pomembnosti zaznane nepravičnosti. Čeprav je vrsta študij (Glick in Fiske, 2001; Jost in Kay, 2005; Karakurt in Cumbie, 2012; Sibley idr., 2007) preučila odnos med ideologijami (npr. upravičevanje sistema), vrednotami (npr. enakosti) ter družbenimi in političnimi stališči (npr. naklonjenost družbenemu nadzoru in avtoritarizmu) in seksizmom, primanjkuje študij, ki bi ugotavljale vpliv aktivacije posameznih stališč na presojo in odziv na različne vrste seksizma.

Avtorji s področja opolnomočenja posameznic in posameznikov (Hur, 2006; Simonet, Narayan in Nelson, 2015) poudarjajo tudi pomen nekaterih drugih psiholoških konstruktov pri spoprijemanju $\mathrm{z}$ diskriminacijo. Hur (2006) poleg zaznane pomembnosti problema izpostavlja sledeče: kompetentnost (samoučinkovitost, mojstrstvo), samodoločenost (lokus kontrole) in občutek vplivnosti (samozadostnost, sprejemanje odločitev). Simonet s sodelavci (2015) pa navedenim dodaja še občutek psihološke varnosti. Psihološki dejavniki opolnomočenja skupaj s kolektivnimi (združevanje $\mathrm{v}$ skupno prizadevanje) niso le vodilo individualnih, temveč tudi družbenih sprememb. $\mathrm{V}$ bodočih raziskavah zato predlagam raziskovanje potenciala, ki ga ima psihološko opolnomočenje, pri zavračanju in preseganju seksizma.

Za oblikovanje družbeno-transformativnih prizadevanj na področju enakosti med spoloma namreč ni dovolj le prepoznati in razumeti delovanje ambivalentnega seksizma, temveč je ključno ugotoviti, katere strategije so učinkovite pri povečanju občutljivosti na seksizem, krepitvi odklonilnega odnosa do njega in spodbujanju aktivnega soočanja in odpravljanja seksizma. Zato je pomembno, da se bodoče raziskave usmerijo na ugotavljanje: (1) dejavnikov tveganja za razvoj oziroma ponotranjenje seksističnih stališč, (2) dejavnikov, ki povečujejo tolerantnost do dobronamernega in sovražnega seksizma, (3) značilnosti ranljivih skupin (tako žrtev seksizma kot tudi seksistov samih), (4) okoliščin oziroma okolij (zasebnih, javnih, delovnih) in načinov manifestiranja seksizma ter (5) učinkovitih načinov za spoprijemanje z njim, vključno s psihološkim opolnomočenjem ranljivih skupin in žrtev seksizma. 


\section{Literatura}

Abrams, D., Masser, B. in Bohner, G. (2003). Perceptions of stranger and acquaintance rape: The role of benevolent and hostile sexism in victim blame and rape proclivity. Journal of Personality and Social Psychology, 84, 111-125.

Barreto, M., Ellemers, N., Piebinga, L. in Moya, M. (2010). How nice of us and how dumb of me: The effect of exposure to benevolent sexism on women's task and relational self-descriptions. Sex Roles, 62, 532-544.

Becker, J. C. in Swim, J. K. (2012). Reducing endorsement of benevolent and modern sexist beliefs. Social Psychology, 43(3), 127-137.

Calogero, R. M. in Jost, J. T. (2011). Self-subjugation among women: Exposure to sexist ideology, self-objectification, and the protective function of the need to avoid closure. Journal of Personality and Social Psychology, 100(2), 211-228.

Campbell, B., Schellenberg, G. E. in Senn, C. Y. (1997). Evaluating measures of contemporary sexism. Psychology of Women Quarterly, 21, 89-102.

Chen, Z., Fiske, S. T. in Lee, T. L. (2009). Ambivalent sexism and power-related gender-role ideology in marriage. Sex Roles, 60, 765-778.

Chisango, T., Mayekiso, T. in Thomae, M. (2015). The social nature of benevolent sexism and the antisocial nature of hostile sexism: Is benevolent sexism more likely to manifest in public contexts and hostile sexism in private contexts? International Journal of Psychology, 50(5), 363-371.

Connelly, K. in Heesacker, M. (2012). Why is benevolent sexism appealing? Associations with system justification and life satisfaction. Psychology of Women Quarterly, 36(4), 432-443.

Crosby, F., Bromley, S. in Saxe, L. (1980). Recent unobtrusive studies of Black and White discrimination and prejudice: A literature review. Psychological Bulletin, 87, 546-563.

Dardenne, B., Dumont, M. in Bollier, T. (2007). Insidious dangers of benevolent sexism: Consequences for women's performance. Journal of Personality and Social Psychology, 93, 764-779.

Dovidio, J. F. in Gaertner, S. L. (1986). The aversive form of racism. V J. F. Dovidio in S. L. Gaertmer (ur.), Prejudice, discrimination, and racism (str. 61-89). Orlando, FL, ZDA: Academic Press.

Dumont, M., Sarlet, M. in Dardenne, B. (2010). Be too kind to a woman, she'll feel incompetent: Benevolent sexism shifts self-construal and autobiographical memories toward incompetence. Sex Roles, 62, 545-553.

Duran, M., Moya, M. in Megías, J. L. (2014). Benevolent sexist ideology attributed to an abusive partner decreases women's active coping responses to acts of sexual violence. Journal of Interpersonal Violence, 29(8), 1380-1401.

Duran, M., Moya, M., Megias, J. L. in Viki, T. G. (2010). Social perception of rape victims in dating and married relationships: The role of perpetrator's benevolent sexism. Sex Roles, 62, 505-519.
Eagly, A. H. in Mladinic, A. (1989). Gender stereotypes and attitudes towarrd women and men. Personality and Social Psychology Bulletin, 15(4), 543-558.

Eastwick, P. W., Eagly, A. H., Glick, P., Johannesen-Schmidt, M. C., Fiske, S. T., Blum, A. M. B. ... Volpato C. (2006). Is traditional gender ideology associated with sex-typed mate preferences? A test in nine nations. Sex Roles, 54, 603-614.

Forbes, G. B., Collinsworth, L. L., Jobe, R. L., Braun, K. D. in Wise, L. M. (2007). Sexism, hostility toward women, and endorsement of beauty ideals and practices: Are beauty ideals associated with oppressive belifs? Sex Roles, 56, 265-273.

Forbes, G. B., Doroszewicz, K., Card, K. in Adams-Curtis, L. (2004). Association of the Thin body ideal, ambivalent sexism, and self-esteem with body acceptance and the preferred body size of college women in Poland and the United States. Sex Roles, 50, 331-345.

Forbes, G. B., Jung, J. in Haas, K. B. (2006). Benevolent sexism and cosmetic use: A replication with three college samples and one adult sample. The Journal of Social Psychology, 146(5), 635-640.

Franzoi, S. L. (2001). Is female body esteem shaped by benevolent sexism? Sex Roles, 44, 177-188.

Glick, P. in Fiske, S. T. (1996). The Ambivalent Sexism Inventory: Differentiating hostile and benevolent sexism. Journal of Personality and Social Psychology, 70, 491-512.

Glick, P. in Fiske, S. T. (1997). Hostile and benevolent sexism: Measuring ambivalent sexist attitudes toward women. Psychology of Women Quarterly, 21(1), 119-135.

Glick, P. in Fiske, S. T. (1999). The Ambivalence Toward Men Inventory: Differentiating hostile and benevolent sexism. Psychology of Women Quarterly, 23, 519-536.

Glick, P. in Fiske, S. T. (2001). An ambivalent alliance: Hostile and benevolent sexism as complementary justifications for gender inequality. American Psychologist, 56(2), 109-118.

Glick, P. in Fiske, S. T. (2011). Ambivalent sexism revisited. Psychology of Women Quarterly, 35(3), 530-535.

Glick, P., Diebold, J., Bailey-Werner, B. in Zhu, L. (1997). The two faces of Adam: Ambivalent sexism and polarized attitudes toward women. Personality and Social Psychology Bulletin, 23(12), 1323-1334.

Glick, P., Fiske, S. T., Mladinic, A., Saiz, J. L., Abrams, D., Masser, B., ... Lopez, W. (2000). Beyond prejudice as simple antipathy: Hostile and benevolent sexism across cultures. Journal of Personality and Social Psychology, 79(5), 763-775.

Glick, P., Lameiras, M., Fiske, S. T., Eckes, T., Masser, B., Volpato, C., ... Wells, R. (2004). Bad but bold: Ambivalent attitudes toward men predict gender inequality in 16 nations. Journal of Personality and Social Psychology, 86(5), 713-728.

Goldstein, N. J. in Mortensen, C. R. (2012) Social norms: A how-to (and how-not-to) guide. V D. T. Kenrick, N. J. Goldstein in S. L. Braver (ur.), Six degrees of social influence: Science, application, and the psychology of Robert Caldini (str. 68-78). New York, NY, ZDA: Oxford University Press. 
Good, J. J. in Rudman, L. A. (2010). When female applicants meet sexist interviewers: The costs of being a target of benevolent sexism. Sex Roles, 62, 481-493.

Hammond, M. D. in Sibley, C. G. (2011). Why are benevolent sexists happier? Sex Roles, 65, 332-343.

Hur, M. H. (2006). Empowerment in terms of theoretical perspectives: Exploring a typology of the process and components across disciplines. Journal of Community Psychology, 34(5), 523.

Jackman, M. R. (1994). Paternalism and conflict in gender, class and race relations. Berkeley, CA, ZDA: University of California Press.

Jost, J. T. in Banaji, M. R. (1994). The role of stereotyping in system-justification and the production of false consciousness. British Journal of Social Psychology, 33(1), 1-27.

Jost, J. T., Banaji, M. R. in Nosek, B. A. (2004). A decade of system justification theory: Accumulated evidence of conscious and unconscious bolstering of the status quo. Political Psychology, 25(4), 881-919.

Jost, J. T. in Kay, A. C. (2005). Exposure to benevolent sexism and complementary gender stereotypes: Consequences for specific and diffuse forms of system justification. Journal of Personality and Social Psychology, 88(3), 498-509.

Karakurt, G. in Cumbie, T. (2012). The relationship between egalitarianism, dominance, and violence in intimate relationships. Journal of Family Violence, 27(2), $115-122$.

Katz, I. (1981). Stigma: A social psychological analysis. Hillsdale, MI, ZDA: Lawrence Erlbaum.

Kilianski, S. E. in Rudman, L. A. (1998). Wanting it both ways: Do women approve of benevolent sexism? Sex Roles, 39, 333-352.

King, E. B., Botsford, W., Hebl, M. R., Kazama, S., Dawson, J. F. in Perkins, A. (2012). Benevolent sexism at work: Gender differences in the distribution of challenging developmental experiences. Journal of Management, 38(6), 1835-1866.

Lee, T. L., Fiske, S. T., Glick, P. in Chen, Z. (2010). Ambivalent sexism in close relationships: (Hostile) power and (benevolent) romance shape relationship ideals. Sex Roles, 62, 583-601.

Liviatan, I. in Jost, J. T. (2011). System justification theory: Motivated social cognition in the service of the status quo. Social Cognition, 29(3), 231-237.

Masser, B. in Abrams, D. (1999). Contemporary sexism: The relationships among hostility, benevolence, and neosexism. Psychology of Women Quarterly, 23, 503-517.

McConahay, J. B. (1986). Modern racism, ambivalence, and the Modern Racism Scale. V J. F. Dovidio in S. L. Gaertmer (ur.), Prejudice, discrimination, and racism (str. 91-125). Orlando, FL, ZDA: Academic Press.

McConahay, J. B. in Hough, J. C. (1976). Symbolic racism. Journal of Social Issues, 32(2), 23-45.

Montanes, P., de Lemus, S., Bohner, G., Megias, J. L., Moya, M. in Garcia-Retamero, R. (2012). Intergenerational transmission of benevolent sexism from mothers to daughters and its relation to daughters' academic performance and goals. Sex Roles, 66, 468-478.
Moya, M., Glick, P., Expósito, F., de Lemus, S. in Hart, J. (2007). It's for your own good: Benevolent sexism and women's reactions to protectively justified restrictions. Personality and Social Psychology Bulletin, 33, 1421-1434.

Muehlenkamp, J. J. in Saris-Baglama, R. N. (2002). Selfobjectification and its psychological outcomes for college women. Psychology of Women Quarterly, 26(4), 371-379.

Myers, D. G. (2010). Social psychology (5. izd.). New York, NY, ZDA: McGraw-Hill.

Napier, J. L., Thorisdottir, H. in Jost, J. T. (2010). The joy of sexism? A multinational investigation of hostile and benevolent justifications for gender inequality and their relations to subjective well-being. Sex Roles, 62, 405-419.

Rudman, L. A. in Glick, P. (2010). The social psychology of gender: How power and intimacy shape gender relations. New York, NY, ZDA: Guilford Press.

Rudman, L. A. in Heppen, J. B. (2003). Implicit romantic fantasies and women's interest in personal power: A glass slipper effect? Personality and Social Psychology Bulletin, 29, 1357-1370.

Russell, B. L. in Trigg, K. Y. (2004). Tolerance of sexual harassment: An examination of gender differences, ambivalent sexism, social dominance, and gender roles. Sex Roles, 50, 565-573.

Sakalh, N. (2001). Beliefs about wife beating among Turkish college students: The effect of patriarchy, sexism, and sex differences. Sex Roles, 44, 599-610.

Saunders, K. J. in Kashubeck-West, S. (2006). The relations among feminist identity development, gender-role orientation, and psychological well-being in women. Psychology of Women Quarterly, 30(2), 199-211.

Shepherd, M., Erchull, M. J., Rosner, A., Taubenberger, L., Forsyth Queen, E. in McKee, J. (2011). I'll get that for you: The relationship between benevolent sexism and body self-perceptions. Sex Roles, 64, 1-8.

Sibley, C. G., Wilson, M. S. W. in Duckitt, J. (2007). Antecedents of men's hostile and benevolent sexism: The dual roles of social dominance orientation and right-wing authoritarianism. Personality and Social Psychology Bulletin, 33(2), 160-172.

Simonet, D. V., Narayan, A. in Nelson, C. A. (2015). A socialcognitive moderated mediated model of psychological safety and empowerment. The Journal of Psychology, 149(8), 818-845.

Spence, J. T. in Helmreich, R. L. (1972). The Attitudes toward Women Scale: An objective instrument to measure attitudes toward the rights and roles of women in contemporary society. JSAS Catalog of Selected Documents in Psychology, 2, 66-67.

Swim, J. K., Aikin, K. J., Hall, W. S. in Hunter, B. A. (1995). Sexism and racism: Old fashioned and modern prejudices. Journal of Personalty and Social Psychology, 27, 1673-1682.

Tougas, F., Brown, R., Beaton, A. M. in Joly, S. (1995). Neosexism: Plus ça change, plus c'est pareil. Personality and Social Psychology Bulletin, 21, 842-849. 
Travaglia, L. K., Overall, N. C. in Sibley, C. G. (2009). Benevolent and hostile sexism and preferences for romantic partners. Personality and Individual Differences, 47, 599-604.

Ule, M. (2009). Socialna psihologija: Analitični pristop $k$ življenju v družbi. Ljubljana, Slovenija: Založba FDV.

Viki, T. G. in Abrams, D. (2002). But she was unfaithful: Benevolent sexism and reactions to rape victims who violate traditional gender role expectations. Sex Roles, 47, 289-293.

Viki, G. T., Abrams, D. in Hutchison, P. (2003). The "true" romantic: Benevolent sexism and paternalistic chivalry. Sex Roles, 49, 533-537.

Viki, G. T., Abrams, D. in Masser, B. (2004). Evaluating stranger and acquaintance rape: The role of benevolent sexism in perpetrator blame and recommended sentence length. Law and Human Behavior, 28(3), 295-303. 